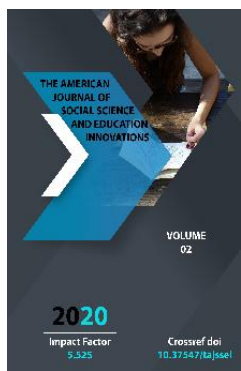

\title{
The Essence Of The Organization Of Synergetic Integration Of Science, Education, Industry In Uzbekistan
}

\section{Saydaliev I.N.}

Senior Teacher,Andijan Machine-Building Institute, Uzbekistan

Journal Website: http://usajournalshub.c om/index,php/tajssei

\section{ABSTRACT}

The article considers the issues of synergetic integration of education, science and production.

\section{KEYWORDS}

Integration, science, education, production, efficiency, engineer.

\section{INTRODUCTION}

Everyone knows that the means of communication began to have a direct impact on all spheres of economic and spiritual activity of a person, turned into an international means of interaction and mutual influence of states, industries, firms and even individual specialists. A high level of interaction between science, education and production has arisen, since the carriers of information here are often the same persons, specialists, who use a single information environment. Integration processes between the activities under consideration, firstly, are economical and effective, secondly, they accelerate scientific and technological progress, and thirdly, they allow rational use of the intellectual potential of science and higher education not only in a single country, but also in the world community as a whole. Summarizing, analyzing and leveraging this experience can bring tremendous benefits to all those involved in this process.

The integration of education, science and production provides for their organic combination in the preparation of a student in a chosen specialty at a university. The effect of such a combination essentially depends on the form of its implementation, and the open space of education is built in the form of a system of formal and informal relations that 
provide the student (regardless of his nationality or state affiliation) with uniform opportunities for professional growth and subsequent activities in accordance with the training received [1 -3$]$.

Areas of integration of education, science and production have numerous forms of implementation:

- Educational and research and production complexes;

- $\quad$ Systems "plant-technical college" or "Phystech;

- $\quad$ Branches and basic departments;

- Scientific, educational and engineering centers;

- Systems of targeted intensive (individual) training of students;

- $\quad$ Technoparks and technopolises;

- Creative teams of specialists, students, etc.

Each of these forms, in turn, has its own characteristics in different conditions and specific educational institutions. At the same time, each form has common features, which formed the basis for their definition.

Synergetic integration implies that two systems work together. In doing so, both systems try to achieve the goal they have set for themselves and to achieving more than they have achieved on their own. Research and the scientific pedagogical literature have shown that synergetic integration is a multifaceted complex concept that represents processes in many areas. Synergetic integration in the laws of nature, in the socioeconomic, political, and cultural spheres, in the education system via interdisciplinary and interdepartmental cooperation, in the training of modern engineers, in higher education and in production are vivid examples. In conclusion, it would be expedient for us to ensure a synergetic integration of higher education and production in the training of modern engineers.

\section{MATERIALS AND METHODS}

In relation to the training of modern engineers, we attempt to define the term synergetic integration of higher education and industry as the manifestation of intellectual products created in each subsystem integrated into a whole to create a single educational space that includes the technical university, science and industry, demonstrating a strong potential for creative development of all subjects. This approach represents a collaborative creative activity to achieve quality and innovative training of modern engineers. This type of integration involves not only the training of modern engineers but also joint activities that carry out pedagogical, technical and socioeconomic tasks in the interests of the two systems (higher education and production). Explaining the social and pedagogical significance of the synergetic integration of higher education and industry is an important task of our research work. Clearly, we emphasize that effective results cannot be achieved without ensuring the integration and implementation mechanism of integrated education and intersystem synergistic integration [4].

Time makes new demands on graduates of higher education. Their professional qualifications are increasingly determined by the scientific basis of their training, the ability to adapt to changing economic conditions, constant replenishment and creative use of their knowledge. A modern specialist must be 
able to coordinate his goals, tasks and actions with the goals, tasks and actions of other people. In many life and work situations, advice and recommendations received during study at a university do not "work", and often become harmful: a young specialist uses them without understanding the essence of a particular situation. The education system, and vocational education in particular, is inextricably linked with the socio-economic formation within which it was formed and exists [3].

Branches and basic departments at enterprises and scientific institutions are the most common form of integration of higher education with science and production in our country. Branches of departments are created for more effective use of the research and laboratory base of enterprises (SRI) in the educational process, as well as for training specialists in new areas, in which the university does not have a teaching and laboratory base. In addition, this form of INSP develops connections between university teachers and enterprise specialists in the field of scientific research.

Branches and basic departments at enterprises and scientific institutions are the most common form of integration of higher education with science and production in our country. Branches of departments are created for more effective use of the research and laboratory base of enterprises in the educational process, as well as for training specialists in new areas, in which the university does not have a teaching and laboratory base. In addition, this form of INSP develops connections between university teachers and enterprise specialists in the field of scientific research.
Technoparks are a relatively new and rather rare form of INNP in Russia (terms are also often used in accordance with the direction of activity: "science park", "technology park", "science and technology park", etc.) and technopolises. This form of INNP is a research and production, educational and socio-cultural zone, united around a scientific center (university, large university), to ensure a continuous innovation cycle, the practical use of scientific and technological achievements, and the commercialization of research and development and $R \& D$ results. At the initial stage of the merger, as a rule, this form is implemented in the form of a "science park", and after a while (2-3 years), when the results of scientific and technical developments appear and the need arises to attract modern science-intensive production, such a park becomes a "scientific and technological park ". Technoparks are widespread in Great Britain and the USA. Technopolises are technoparks of a large, sometimes international scale, which are widespread in Japan. They are multipurpose. Thanks to them, the introduction of new technologies is sharply accelerated, and fundamental science, due to intense feedback, receives additional incentives. The quality of education is improving; a new socio-cultural environment is being created in the region [1-3].

\section{DISCUSSIONS AND RESULTS}

In many countries of the world, including Uzbekistan, a versatile form of integration is educational, research and production centers (URPC), the functioning of which is implemented through a contractual form of cooperation between a university and an enterprise, providing effective training and solving fundamental scientific and technical 
problems, reducing the timing of the introduction of scientific ideas into production and the training of scientific and engineering personnel with a target bias in the relevant specialty.

Integration in the form of "Branches and basic departments" is the most common form of integration of "Education, Science and Production" in the Andijan Machine-Building Institute, and in general in Uzbekistan. Branches of departments are created for more effective use of the research and laboratory facilities of enterprises in the educational process, as well as for training specialists in new areas, in which the university lacks a modern educational and laboratory base. Especially, this form of integration develops connections between university teachers and enterprise specialists in the field of scientific research.

Engineering groups are being created at the Andijan Machine-Building Institute to solve problems related to the development of new systems of machines, technologies and engineering programs, their introduction into production, training (retraining, advanced training) of personnel, for the subsequent maintenance of new equipment and technologies. And creative teams of teachers and technical circles of students who are involved in scientific, engineering and commercial activities, have a beneficial effect on the development of the creative abilities of future specialists, affect the quality of training.

\section{CONCLUSION}

At the institute, together with Uz-Auto Motors JSC, elite groups of 1 and 2 courses have been created in the specialties of
Mechanical Engineering and Automotive Engineering in English language of instruction, the purpose of which is to train personnel for JSC Uzavtosanoat of the Republic of Uzbekistan. The international program "SYNERGY: Creation of Synergetic Integration of Higher Education and Production in Uzbekistan" financed by the Ministry of Higher Education and Education of the Republic of Uzbekistan is in operation.

As in Russia and our country, a relatively new form of integration of "Education, Science and Industry" is technoparks. This form of integration is an educational, scientific and production zone, united around a scientific center - a university, to ensure a continuous innovation cycle, the practical use of scientific and technological achievements, and the commercialization of research results.

\section{REFERENCES}

1. Targeted training of specialists at faculties at customer enterprises / V.N. Gerdi, A.A. Dorofeev and V.I. Zavarzin, S.S. Yudachev. // Flight. 2000. Special. graduation - MSTU named after N.E. Bauman -170 years old. P. 67-70.

2. Zavarzin V.I. Continuous research and production practice. // All-Russian scientific-practical conference "Strategy for the development of university technical education in Russia". Moscow, November 23-24, 2000: Abstracts. - M .: Publishing house of MSTU im. N.E. Bauman. 2000.P. 93, 94.

3. Zavarzin V.I., Goev A.I. Integration of education, science and industry // Russian Entrepreneurship. - 2001. - Volume 2. - No. 4. - P. 48-56.4. 
4. Saydaliev IN, The essence of the content of synergetic integration of higher education and production // International scientific-practical conference: Andijan Machine-Building Institute.- 2020. P.278287

5. Yusupovich, K. S. (2020). The Emergence Of Religious Views Is Exemplified By The Southern Regions. The American Journal of Social Science and Education Innovations, 2(10), 143-145. 